\title{
Fun Is Serious Business: Digital Natives and Digital Technologies in Construction Education
}

\author{
Lydia Kiroff \\ Unitec Institute of Technology \\ Taija Puolitaival \\ Unitec Institute of Technology
}

\begin{abstract}
Digital technologies are becoming increasingly wide-spread not just in our personal but also in our professional lives. Younger generations, born into a world of vast technological advances and innovations, are constantly connected expecting immediate response. Despite the relatively later adoption of digital technology in the Architecture, Engineering and Construction (AEC) industry, it has now become a permanent part of its successful operation with one such example being Building Information Modelling (BIM). This study employed a survey research approach to investigate how digital natives cope with the use of digital construction technologies in an education context. The findings suggest that the students on the course prefer mobile devices over desktop computers, stay connected continuously by using a wide variety of social media applications, learn new construction-specific freeware intuitively and by experimenting rather than following step-by-step instructions, and especially value the use of diverse specialist software to aid their learning. These findings could have potential implications for the future design of learning spaces, the way connectivity is considered in delivery and assessment, and the continual upskilling of the older generation faculty to address the constantly evolving learning preferences of the digital natives.
\end{abstract}

Keywords: digital natives; digital technologies; construction education, construction-specific freeware

\section{INTRODUCTION}

Digitalisation is changing our lives, both personal and professional. Many of us are constantly connected through technology to our social and work contacts, and use a number of applications for leisure and work purposes. Not many areas of society have remained untouched by the advent of digital technologies. The Architecture, Construction and Engineering (AEC) industry has been one of the last industries, which has experienced the Digital Revolution, or Industry 4.0, in today's technological parlance (Lu, 2017; Zezulka et al., 2016). Applications which are part of our everyday lives have also become part of our everyday business. At the same time, there are also applications, which have been developed specifically for the purposes of certain industries. In the AEC industry one of the most transforming digital technologies is Building Information Modelling (BIM) (Azhar, Khalfan \& Maqsood, 2012; Osterreich \& Teuteberg, 2016). It is a combination of technology and processes to deliver design and support construction, operation and maintenance of the building in a collaborative way. The use of BIM requires 
sound understanding of the processes, but also necessary skills in the related technology use. There are hundreds of different software applications which can be used for the purposes of BIM. Some of these are online applications, some freeware and some are license-requiring desktop applications. The functions and the difficulty of the application usually increases when moving from online applications and freeware to desktop applications.

The younger generations, born into a world of vast technological advances and innovations, have limited or no experience in manual processes such as writing a letter on paper, using a landline phone or a fax machine, or searching information from physical books or archives. Their first contact with digital technology might have already been in their first years using a tablet or a mobile phone to watch a video or play a simple game. Young adults are used to instant communication using mobile phones and social media applications, having very little tolerance for delays in communication (Farrow, Liu, \& Tatum, 2011); they simply don't know a life without digital technology.

There is a natural discrepancy in how digital technology is perceived by faculty and students (Farrow, Liu, \& Tatum, 2011), when faculty is mostly born between 1960 and 1980 and tertiary students mostly between 1980 and 2002. The faculty generation was born in a time when there was not much, if any, digital technology in use in everyday lives. While growing up, they got gradually used to computers, owning and using mobile phones and later other mobile devices. Constant connectivity and social media are something that they have learned as adults, not something that they have grown up with.

There is a vast amount of literature on digital natives and digital learning technologies in general. However, limited studies examine how digital natives cope with discipline-specific applications and even fewer, if any, explore these issues in the AEC disciplines. To fill this gap in the literature, the study has the following aims: First, to empirically document the degree to which incoming first year students on a construction degree access and use general and specialist computer-based technologies as well as various social media applications. Second, to evaluate students' experiences in terms of course content and acquiring new skills. Third, to determine the perceived value that students see in using construction-specific technologies on a course to support their tertiary studies.

\section{BACKGROUND}

\section{Research Context}

The main government agencies with a responsibility for tertiary education in New Zealand are the Ministry of Education (MOE) which is responsible for developing the policy framework for tertiary education, the Tertiary Education Commission (TEC) which is responsible for operating the government's funding mechanisms and giving effect to government strategy, and the New Zealand Qualifications Authority (NZQA) which provides an overarching quality assurance role for the tertiary sector. The Tertiary Education Strategy, which has been jointly developed by the MOE and Ministry of Business, Innovation and Employment (MBIE), sets out the Government's long-term strategic direction for tertiary education. The strategy focuses on ensuring an outward-facing and engaged tertiary education system, with strong links to industry, community and the global economy (Ministry of Education, 2020). On the other hand, NZQA is in charge of degree approval, accreditation and monitoring of degree programmes delivered by New Zealand Institute of Skills and Technology (NZIST) subsidiaries, wānanga (a publicly-owned tertiary institution that provides education in a Māori cultural context) and private training establishments. Threeyear Bachelor of Construction undergraduate degrees are offered by a number of Institutes of Technology under the umbrella of the NZIST. The programme curriculum comprises a mix of compulsory and elective courses at levels 5,6 and 7. Each course is developed with the input of construction professionals, ensuring career relevance. Graduates have real-world, employer-demanded knowledge and skills they can immediately use on the job.

The Bachelor of Construction degree in this research has three majors: Construction Economics, Construction Management and Property Development. This study focuses on students enrolled in semester 1, 2019 in a level 5 elective course, Construction Communication and Documentation, which can be taken 
by students enrolled in any of the three majors. The course was designed by the authors of this research and first launched in 2018. The course has the following learning outcomes:

a) communicate technical concepts and findings in written and graphical formats;

b) understand the basic concepts of design processes, documentation and management;

c) use a range of construction drawings as a communication technique to present ideas and data.

The course has a high proportion of self-directed learning, 102 hours out of a total of 150 , leaving only 48 hours for directed learning. The course design aimed at introducing construction concepts gradually in an engaging way through the use of construction-specific freeware - Solibri Model Viewer, Tekla BIMsight, Tekla Field 3D and Padlet, which the students had to learn on their own using the online course resources and tutorials provided for them. These resources were a mix of YouTube videos, step-by-step written instructions and software training manuals. Construction jargon was kept to a minimum as the majority of students lacked any construction knowledge when starting the course.

To understand the study context further it needs to be noted, that unlike most undergraduate construction programmes in Europe or in North America, New Zealand construction degrees do not include engineering subjects. Instead there is a base of construction technology courses with limited structural calculations and a greater focus on the specialisation or the major. In the case of the specific NZIST subsidiary, students choose Construction Economics, Construction Management or Property Development, or two of these as their major. When they graduate they are responsible for using Building Information Models for viewing, analysing and simulation purposes, not for design. This has direct implications for the selection of software on the course.

\section{The Digital Natives' Narrative in Tertiary Education}

The profile of tertiary education students is ever-changing with the majority nowadays being millennials/net generation/generation Y/digital natives born between 1980 and 2000 (Carlson, 2005; Farrow, Liu, \& Tatum, 2011; Yan, 2006; Zhao, McCoy, Bulbul, Fiori, \& Nikkhoo, 2015). Furthermore, the next generation, Generation Z, born between 1995-2005, is disrupting the way learning typically happens in higher education (Azhar, Kim, \& Salman, 2018). Today's students represent the first generations to grow up with the technologies of the digital age - computers, videogames, digital music players, video cams, cell phones (Prensky, 2001a), have a natural ability to use them, and show a great affinity for integrating new tools and mobile devices in their daily activities connecting to each other via social media, performing several tasks simultaneously, and playing strategic and collaborative games on their mobile devices (Behzadan, Vassign, \& Mostafavi, 2016). Prensky (2001a) coined the term "digital natives" to describe these new students of today who are the "native speakers" of the digital language of computers, video games, instant messaging and the Internet. As a result of the ubiquitous technology environment, today's students think and process information fundamentally differently from their predecessors (Prensky, 2001a). Howe and Strauss (2007) termed these "special, sheltered, confident, team-oriented, achieving, pressured and conventional" new generation students - "millennials".

Some of the collective characteristics of this new generation of students are their ability to multitask, access information in a random fashion through "hypertext" approaches, strong preference for visuals and graphics rather than text, games to "serious" work, and staying permanently connected, even overconnected, in a kind of digital hyper-activity (UNESCO, 2011). The fascination with technology is immense (Howe \& Strauss, 2005); students commonly attempt to juggle a text message conversation with surfing the Web and completing a reading assignment at the same time. They often carry various electronic devices where portability of the device is paramount (Farrow et al., 2011).

The tolerance for traditional lecturing, step-by-step guides and detailed instructions is very low (Prensky, 2001a). Linear thought processes that dominate educational systems now can actually retard learning for brains developed through game and Web-surfing processes on the computer (Prensky, 2001b). Instead, students have a "bias toward action" (Brown, 2000), a strong preference for experiential and handson learning to immediately apply knowledge just learned (Farrow et al., 2011). Hence, an active learning approach with access to multiple media sources appeals most to students (Nirmalakhandan, Ricketts, McShannon, \& Barrett, 2007; Oblinger \& Oblinger, 2005). Furthermore, teaching should provide 
opportunities for socialising through student interaction and group work (Oblinger \& Oblinger, 2005) as students enjoy working in groups (Howe \& Strauss, 2000).

Yet, the criticism in the literature is about the inadequate response from the tertiary sector especially in the areas of teaching construction methods and building design which historically have been over-reliant on traditional pedagogical methods - a lecture format delivery with high use of PowerPoint presentations and minimal use, if any, of technology (Behzadan et al., 2016; Farrow et al., 2011). Traditional education is unprepared for the sophisticated technical skills and learning preferences of these "digital natives" or "net generation" (Bennett, Maton, \& Kervin, 2008). The unintended consequences are low engagement and a lack of interaction with the learning environment, loss of learning aptitude, and loss of knowledge retention (Azhar, Kim, \& Salman, 2018; Behzadan et al., 2016). The short attention spans, that educators often complain about, are mainly associated with the old ways of learning but not with games or anything that actually interests them (Prensky, 2001b). To counteract these undesirable consequences, classroom delivery and assessment should be geared toward teamwork, experiential activities, structure, and the use of technology. Students expect that education will be entertaining (Farrow et al., 2011). However, it should be noted that while digital technologies are central to the ways in which students experience their studies, they are not "transforming" the nature of university teaching and learning (Henderson, Selwyn, \& Aston, 2017). Students seem to still value the "conventional" approaches - first, logically structured, up to date and thought-provoking lecture contents; second, diverse assessment tasks, adequately linked to the lecture contents, to assess a range of students' skills, knowledge, and ability; third, use of diverse teaching methods to keep lectures interesting; fourth, clear communication particularly when teaching complex topics and providing quality feedback; and fifth, knowledgeable, enthusiastic, approachable, helpful and considerate lecturers (Sunindijo, 2016).

\section{Digital Technology Integration in Construction Education}

The ever-increasing use of BIM in the Architecture, Engineering and Construction (AEC) industry has necessitated its integration into course content with the aim to emulate real world environments. Furthermore, Augmented Reality (AR), Virtual Reality (VR), Mixed Reality (MR) and Rapid Prototyping (RP) are also successfully implemented as part of the teaching curricula on an undergraduate and post graduate level. Various studies report on the positive feedback from students that such courses receive. The main benefits are around familiarising with the BIM tools, which students find intuitive and therefore relatively easy to learn (Sacks, \& Barak, 2010), improving general information management skills (Ghosh, Parrish \& Chasey, 2015) as well as creating an enhanced learning environment that facilitates unique learning experiences, engagement and motivation (Behzadan et al., 2016; Vasilevski \& Birt, 2020) thus fostering the search for creative solutions (Leal, Salgado, \& Silvoso, 2018)

In more specific terms, an online construction multimedia library is available on undergraduate construction courses to enhance teaching and learning (Liu, Olsen, \& Hein, 2011). SketchUp is used for 3D modelling and a SketchUp plug-in, 4D Virtual Builder, to assist in teaching structural principles and construction processes to engineer-architects and construction engineers on a Master's course (Kubicki, Guerriero, Leclercq, Nys, \& Halin, 2012). AR is often used as a highly effective visualisation tool with the aim to enhance learning by viewing the real world with the addition of external information, such as adding layers of 2D, 3D and text information (Behzadan et al., 2016; Kim, \& Irizarry, 2020). VR proves useful for providing virtual training to students through simulations on a construction site or in the classroom to understand the construction process sequence and assembly of construction components (Lukas, 2018; Stange, \& Scheer, 2012). Other studies go further to suggest the integration of the BIM platform with AR to superimpose BIM-based model elements and images on real-time site videos or real-world buildings to analyse and understand their operation (Bademosi, Blinn \& Issa, 2019; Behzadan et al., 2016) or with VR to interact with the model in real time and change parameters while working in the virtual environment (Kieferle \& Woessner, 2015). 3D CAD and 3D RP modelling are used as effective methods in teaching construction technology and structural systems to architects and engineers as they offer the advantage of integrating construction techniques with architectural design (Araki, \& Hirano, 2015). Mixed Reality (MR) and Mobile Mixed Reality (MMR) which represent the merger of real and virtual worlds to produce new 
environments and visualizations have been identified as having the potential to reimagine spatial information delivery and enhance higher education practice (Azhar et al., 2018; Vasilevski \& Birt, 2020).

There is a vast amount of literature on BIM education in a tertiary setting, however, there is very limited, if any, research looking into how millennials/generation Y/digital natives experience the use of digital construction technology. In addition, the focus in the literature is more on the final year courses of an undergraduate qualification or on postgraduate courses, offering very little information to those faculty, that are considering to introduce discipline-specific technology early on in the first year of the degree. Limited studies offer insights into the use of technology on first year construction courses, such as first year engineering students on a Communicating Engineering Information course (Sacks \& Barak, 2010), mainly describing the student experience with the BIM software. However, the software and how they are used are engineering-specific and not applicable to the NZIST Bachelor of Construction degree.

\section{RESEARCH APPROACH AND METHODS}

The study employed a survey research approach focusing on the students enrolled in the Construction Communication and Documentation course in semester 1,2019. Surveys are best suited when the researcher wants factual information relating to groups of people: what they do, what they think and who they are, in an attempt to establish patterns of activity within those groups or categories of people (Denscombe, 2014).

Questionnaires, developed specifically for this study, were the major methods of empirical data collection. Two sets of questionnaires, 'start of course' and 'end of course', with a mix of both open-ended and closed questions were used at the very beginning and end of the course. The 'start of course' questionnaire comprised four main sections: demographic information (11 items), access to hardware and the Internet (5 items), use of general computer-based technologies and social media applications (5 and 17 items respectively), and use of specialist computer-based technologies (16 items). The 'end of course' questionnaire comprised three main sections: course content (4 items), acquiring new skills (11 items) and general comments (4 items).

Purposive sampling, which involved all students on the Construction Communication and Documentation course on the Bachelor of Construction degree, was used for this study. In total, 24 students, or a 100 per cent of the class, took part in the survey. Purposive or judgement sampling involves the choice of individuals who are in the best position to provide the information required and is used when a limited number of people have the information that is sought (Cavana, Delahaye \& Sekaran, 2001).

The procedure involved the collection of data at the end of the class in the first and last week of Semester 1, 2019. First, the students were briefed about the project and informed that participation was voluntary and confidential. Only hard copy questionnaires were handed out to keep student identities confidential. The students then completed the questionnaires and returned them putting them in a pile face down. The next step was for the researchers to create two separate data mapping documents/Excel spreadsheets to capture all the data from the two questionnaires completed by each student - one for the start of course and the other one for the end of course questionnaires. This step proved extremely helpful in the process of analysing the data.

\section{RESULTS}

\section{Start of Course Survey \\ Demographic Data}

All students, except one, were born after 1980 and as such fell into the category of "digital natives" described in the literature (Prensky, 2001a; 2001b \& 2007). For the purpose of the analysis and with the aim to compare student attitudes toward the Internet and higher web and social media usage as well as to identify any potential differences, all students were split into three groups: 12 were born between 1985 and 1994; 11 were born between 1995 and 2001; and 1 student was born in 1971. Two generations of "digital natives" have been identified in the literature: those born after 1980, and those born after 1995, the latter belonging to Generation Z. In terms of gender, the class had more male than female students: 15 , or $62.5 \%$, 
were male and 9 students, or $37.5 \%$, were female. The majority of students, 17 , or $70.83 \%$, were from a non-English speaking background (NESB) and 7, or 29.16\%, were from an English-speaking background (ESB). The split between domestic and international students was almost equal: 13 domestic and 11 international students.

The Bachelor of Construction programme has a stair-casing option from lower level qualifications which allows students to continue their construction qualifications at a degree level. Some of the students had used this stair-casing option with 6 of the 24 students holding other construction qualifications: 3 at a certificate and 3 at a diploma level. Nine of the 24 students already had some construction industry experience: 7 had on-site experience, 1 had office and 1 had both. The duration of that experience varied: 4 had 1-year experience, 3 had between 1 and 2 years, 1 had between 2 and 3 years and 1 had 4 years. Having some students with prior construction industry experience proves very useful especially in group work and student-centred learning when experienced students can help the others. An overwhelming number, 17/24 students, had non-construction related work experience in various industry sectors - retail shops, cafes, bars, supermarkets, real estate, phone sales.

In summary, the class consisted exclusively of "digital natives", almost equally split domestic and international, mostly male NESB students. A fourth of the students already had lower level construction qualifications. An overwhelming majority had non-construction related work experience but less than a half had prior construction experience.

Students' Access to Hardware and the Internet

Students were asked about their access to a range of hardware (mobile phones, tablets, laptop computers, desktop computers) and the Internet (Table 1).

TABLE 1

THE PERCENTAGE OF STUDENTS WHO HAVE 'UNLIMITED', 'LIMITED' OR 'NO ACCESS' TO COMPUTER HARDWARE AND THE INTERNET

\begin{tabular}{|l|l|l|l|}
\hline Hardware & Unlimited access & Limited access & No access \\
\hline Mobile phone & $95.8 \%$ & $4.2 \%$ & $0 \%$ \\
\hline Tablet & $25 \%$ & $16.6 \%$ & $58.3 \%$ \\
\hline Laptop computer & $91.7 \%$ & $8.3 \%$ & $0 \%$ \\
\hline Desktop computer & $25 \%$ & $25 \%$ & $50 \%$ \\
\hline Internet & $100 \%$ & $0 \%$ & $0 \%$ \\
\hline
\end{tabular}

Table 1 shows that a very high proportion of students had unlimited access to mobile phones and laptop computers which were the most commonly used devices, none reported 'no access' to either of them. However, tablets and desktop computers did not prove that popular as half of the students had no access to them with only a quarter of the students reporting having 'unlimited access'. All students, without an exception, had 'unlimited access' to the Internet.

\section{Use of General Computer-Based Technologies}

Students were asked to list all the software that they had used to create content, either written, graphical, audio or video, before the commencement of their degree study. All of them had used the MS Office suite: 21 had used Word, Excel and Power Point, 1 had also used Adobe InDesign, 1 - Word and Excel, and 1 Word and Power Point. There were no differences in the range of software used by the two study groups. Table 2 shows how often students used various general computer-based technologies for creating content. 


\section{TABLE 2 \\ PERCENTAGES SHOWING HOW OFTEN STUDENTS USE GENERAL COMPUTER-BASED TECHNOLOGIES}

\begin{tabular}{|l|l|l|l|l|l|}
\hline Computer based technologies & Daily & Weekly & Monthly & $\begin{array}{l}\text { Over } \\
\text { monthly }\end{array}$ & Not used \\
\hline $\begin{array}{l}\text { Use a computer for writing } \\
\text { documents (e.g. Word, etc.) }\end{array}$ & $50 \%$ & $50 \%$ & $0 \%$ & $0 \%$ & $0 \%$ \\
\hline $\begin{array}{l}\text { Use a computer to create } \\
\text { graphics or manipulate digital } \\
\text { images (e.g. Photoshop, } \\
\text { Flash, etc.) }\end{array}$ & $8.3 \%$ & $20.8 \%$ & $29.2 \%$ & $25 \%$ & $16.7 \%$ \\
\hline $\begin{array}{l}\text { Use a computer for creating } \\
\text { multimedia presentations (e.g. } \\
\text { Power Point, etc.) }\end{array}$ & $8.3 \%$ & $33.4 \%$ & $37.5 \%$ & $20.8 \%$ & $0 \%$ \\
\hline $\begin{array}{l}\text { Use a computer for creating } \\
\text { web pages (e.g. } \text { WordPress, } \\
\text { Weebly, etc.) }\end{array}$ & $4.2 \%$ & $4.2 \%$ & $0 \%$ & $25 \%$ & $66.6 \%$ \\
\hline $\begin{array}{l}\text { Use a computer for creating } \\
\text { and editing audio and video } \\
\text { (e.g. iMovie, etc.) }\end{array}$ & $8.3 \%$ & $4.2 \%$ & $4.2 \%$ & $25 \%$ & $58.3 \%$ \\
\hline Other (Please specify) & N/A & N/A & N/A & N/A & N/A \\
\hline
\end{tabular}

Note: Two shades of grey have been used to highlight the usage over $50 \%$ and over $20 \%$.

Based on the data in Table 2, the most frequent activity was writing documents and the most frequently used software for that was Word with half of the students using it daily and the other half - weekly. In comparison, all other software was not that popular especially for daily use - for creating graphics, web pages and multimedia presentations, for manipulating digital images and creating and editing audio and video. The least popular use of computers was for creating web pages with two thirds of the students, or $66.6 \%$, having not used it at all, followed closely by audio and video creation and manipulation with $58.3 \%$ of the students reporting that they had never used it.

In summary, all students, without an exception, started their degree course knowing how to use a computer to write documents and create Power Points. The majority, or $83.3 \%$, had also used software to create graphics or manipulate digital images but that happened infrequently, on a monthly or over monthly basis.

\section{Use of Social Media Applications}

The use of social media has become prolific and an integral part of student social and academic life. Students were asked about their use of a range of popular social media apps. The following is a short glossary of terms: Facebook (an American online social media and social networking service), Facebook Messenger (a messaging app and platform developed by Facebook), YouTube (an American video-sharing platform), WeChat (a Chinese multi-purpose messaging, social media and mobile payment app), WhatsApp (a freeware messaging and Voice over IP service owned by Facebook), Snapchat (an American multimedia messaging app), Instagram (an American photo and video-sharing social networking service owned by Facebook), Twitter (an American microblogging and social networking service), Reddit (an American social news aggregation, web content rating, and discussion website), LinkedIn (an American business and employment-oriented service), Pinterest (an American social media web and mobile application), Viber (a Japanese freeware cross-platform Voice over IP and instant messaging), QQ (a Chinese instant messaging software service and web portal), QZone (a social networking website based in China), Weibo (Chinabased microblogging services), Timblr (an American microblogging and social networking website), LINE 
(a freeware app for instant messaging and Voice over IP). There were no differences in the range of software used by the two study groups. Table 3 shows the frequency of use of various social media.

TABLE 3

PERCENTAGES SHOWING HOW OFTEN STUDENTS USE SOCIAL MEDIA APPLICATIONS

\begin{tabular}{|c|c|c|c|c|c|}
\hline Social networking software & Daily & Weekly & Monthly & $\begin{array}{l}\text { Over } \\
\text { monthly }\end{array}$ & Not used \\
\hline Facebook & $41.6 \%$ & $12.6 \%$ & $4.2 \%$ & $20.8 \%$ & $20.8 \%$ \\
\hline Facebook Messenger & $41.6 \%$ & $20.8 \%$ & $4.2 \%$ & $16.7 \%$ & $16.7 \%$ \\
\hline YouTube & $66.6 \%$ & $25 \%$ & $4.2 \%$ & $0 \%$ & $4.2 \%$ \\
\hline WeChat & $58.4 \%$ & $8.3 \%$ & $4.2 \%$ & $8.3 \%$ & $20.8 \%$ \\
\hline WhatsApp & $25 \%$ & $16.6 \%$ & $8.3 \%$ & $8.3 \%$ & $33.3 \%$ \\
\hline Snapchat & $20.8 \%$ & $4.2 \%$ & $0 \%$ & $12.5 \%$ & $62.5 \%$ \\
\hline Instagram & $37.5 \%$ & $12.5 \%$ & $12.5 \%$ & $0 \%$ & $37.5 \%$ \\
\hline Twitter & $4.2 \%$ & $12.5 \%$ & $8.3 \%$ & $12.5 \%$ & $62.5 \%$ \\
\hline Reddit & $8.3 \%$ & $4.2 \%$ & $12.5 \%$ & $8.3 \%$ & $66.7 \%$ \\
\hline LinkedIn & $4.2 \%$ & $16.6 \%$ & $8.3 \%$ & $16.6 \%$ & $54.3 \%$ \\
\hline Pinterest & $0 \%$ & $12.5 \%$ & $4.2 \%$ & $33.3 \%$ & $50 \%$ \\
\hline Viber & $16.6 \%$ & $4.2 \%$ & $4.2 \%$ & $0 \%$ & $75 \%$ \\
\hline QQ & $8.3 \%$ & $4.2 \%$ & $8.3 \%$ & $12.5 \%$ & $66.7 \%$ \\
\hline QZone & $0 \%$ & $4.2 \%$ & $4.2 \%$ & $4.2 \%$ & $87.4 \%$ \\
\hline Weibo & $12.5 \%$ & $16.6 \%$ & $0 \%$ & $4.2 \%$ & $66.7 \%$ \\
\hline Timblr & $0 \%$ & $8.3 \%$ & $4.2 \%$ & $8.3 \%$ & $79.2 \%$ \\
\hline LINE & $0 \%$ & $0 \%$ & $8.3 \%$ & $4.2 \%$ & $87.5 \%$ \\
\hline Other (Please, specify) & N/A & N/A & N/A & N/A & N/A \\
\hline
\end{tabular}

Note: Two shades of grey have been used to highlight the usage over $50 \%$ and over $20 \%$.

The most frequently used social media apps with the highest daily use percentages were YouTube (66.6\%) and WeChat (58.4\%) followed by Facebook and Messenger both on 41.6\%. However, there were also students who had never used them - 4.2\% had not used YouTube (born in 1994), 16.7\% - Messenger (born in 1992, 1994, 1996), 20.8\% had not used Facebook (born in 1992, 1994, 1996, 1997, 2001) and WeChat (born in 1987, 1991, 1994, 1998, 1999). These results do not suggest any significant differences in the use of social media applications by the two age groups. The least popular software was LINE with $87.5 \%$, QZone with $87.4 \%$ and Timblr with $79.2 \%$ of the students who had never used them. Three other 
software Reddit, QQ and Weibo were also least favourite with $66.7 \%$ of the students who had never used them.

In summary, social networking software is in high daily use by all students. There are distinct preferences toward certain applications such as YouTube, WeChat, Facebook and Messenger from a long list of available online freeware. All 17 surveyed social media applications had been used by the students in the sample with the least popular being LINE, QZone and Timbrl.

\section{Use of Specialist Computer-based Technologies}

The use of specialist construction applications is a requirement on a number of courses on the Bachelor of Construction degree. Students were asked to list all the specialist software that they had used so far either at secondary school, during their previous construction qualification or on another degree course. Table 4 shows the frequency of use of various construction-specific software.

TABLE 4

PERCENTAGES SHOWING HOW OFTEN STUDENTS USE
CONSTRUCTION-SPECIFIC SOFTWARE

\begin{tabular}{|l|l|l|l|l|l|}
\hline Construction specific software & Daily & Weekly & Monthly & Over monthly & Not used \\
\hline Solibri Model Viewer & $0 \%$ & $4.2 \%$ & $0 \%$ & $0 \%$ & $95.8 \%$ \\
\hline Solibri Model Checker & $0 \%$ & $4.2 \%$ & $0 \%$ & $0 \%$ & $95.8 \%$ \\
\hline Tekla BIMsight & $0 \%$ & $0 \%$ & $0 \%$ & $0 \%$ & $100 \%$ \\
\hline Tekla Field 3D & $0 \%$ & $0 \%$ & $0 \%$ & $0 \%$ & $100 \%$ \\
\hline SketchUp & $0 \%$ & $16.6 \%$ & $16.6 \%$ & $45.8 \%$ & $21 \%$ \\
\hline AutoCAD & $0 \%$ & $0 \%$ & $4.2 \%$ & $4.2 \%$ & $91.6 \%$ \\
\hline ArchiCAD & $0 \%$ & $0 \%$ & $4.2 \%$ & $4.2 \%$ & $91.6 \%$ \\
\hline Revit & $0 \%$ & $0 \%$ & $0 \%$ & $4.2 \%$ & $95.8 \%$ \\
\hline Navisworks & $0 \%$ & $0 \%$ & $0 \%$ & $4.2 \%$ & $95.8 \%$ \\
\hline CostX & $0 \%$ & $0 \%$ & $0 \%$ & $16.6 \%$ & $83.4 \%$ \\
\hline Other (Please, specify) & N/A & N/A & N/A & N/A & N/A \\
\hline
\end{tabular}

Four of the ten construction specific software that were surveyed are freeware. SketchUp was the software used the most at $45.8 \%$, albeit over monthly. The majority of these students used it on another course as part of the Bachelor of Construction degree and 3 students learned it at school. CostX, which is also used on some other degree courses, was in second place at $16.6 \%$ with an over monthly usage. The use of the remaining software packages was very poor or they were not used at all.

In summary, the majority of students had not used any specialist construction software at the commencement of the Construction Communication and Documentation course. There were a few exceptions, students who had used SketchUp as part of another degree course, previous construction qualification or at secondary school. However, the limited specialist digital proficiency was more than counterbalanced by their excellent overall digital literacy and exceptional social networking software abilities. 


\section{End of Course Survey \\ Course Content}

Each 4-hour lesson on the course dealt with a different topic, such as 'Residential 3D models and 2D drawing sets', 'Commercial 3D models and 2D drawing sets', 'Integrated 2D, 3D \& site analysis for commercial construction'. The majority of students provided very positive feedback on the course content with 17/24 students describing it as "interesting" and 4/24 students thinking that it was also "fun". The overall student feedback was that the course was "useful", "very helpful" and "very informative". Some of the comments that the students made were: "using different IFCs is interesting", "learning about the different software architects and engineers use was interesting, having that bit of insight into what these designers do", "I was interested in dealing with $3 D$ models using software". However, 2/24 students, or $8.3 \%$ of the whole class, had less positive experience with one of them commenting that the course was "hard work". It is worth noting that one of these students was born in 1971 and as such was outside the "digital natives" definition. As mentioned above all other students in the class belonged to the category of "digital natives".

The students were asked to rate the software-based course work and assessments on a scale of 1 (very easy) to 5 (very hard). The majority of students, $16 / 24$, or $66.66 \%$, thought that the work was neither easy nor hard; $6 / 24$ students, or $4.16 \%$, thought that it was easy; for 1 student it was hard and for another one very hard. Some of the comments that were made were: "it takes a while to get familiar with the software but it is easy to use after grasping the skills", "it's hard but can be learned", "the assignments are not very hard but the software is new for our study", "depends if you do the reading or follow lecturer's instructions such as watch software tutorial prior to class", "after learning the tutorials of the software it is not hard as I expected", "the timeframe is challenging but the work is doable", "clear guidance, enough time to practise and think", "being a first time user makes it a bit hard to use but it is interesting to use them", "it is good to have a basic understanding of different software", "the software are pretty straight forward when you get used to them".

An overwhelming majority of students, $19 / 24$, or $79.16 \%$, valued especially the use of diverse specialist software on the course to aid their learning and $5 / 24$, or $20.83 \%$, did not provide comments. The question about the most important things learned on the course elicited very similar comments: "knowing different construction software", "how to explore a new construction software by myself", "reading drawings, handling software", "the use of different software to design and construct buildings, how architecture plans are read, the process you need to take if you want to construct/build anything that requires a building consent", "using the appropriate software, 3D models", "the building industry information and the industry specific information, real life examples and introduction to the contemporary software and companies", "how to use software, things from the lecture, the other information that you wouldn't get from online resources from someone that has worked in the industry".

In summary, the majority of students found the course useful, informative, interesting and fun and particularly valued the use of specialist construction software to aid their learning.

\section{Acquiring New Skills}

The course is centred around acquiring new construction-specific skills. The main challenges came from the lack of prior construction knowledge and practical experience. Since the course has a very high proportion of self-directed learning, it was important to understand what helped the students their learning on the course. Based on the student feedback, they found a diverse range of resources very helpful: "good lecturing", "software and PowerPoints", "Moodle material and Google searches", "assignments", "the use of external resources", "interacting with the class when there are group activities", "the lecture presentations, they actually give a lot of help for learning this course", "the software that are used in the industry and the lectures before we start work". Some of the limitations or obstacles that got in the way of learning were: "some software can't run or be installed on Mac, e.g. BIMsight", "pro vocabulary", "too much work from other assignments", "sometimes limited knowledge is a factor", "not enough time". A few students were even self-critical: "personal time management", "myself not attending class on time or missed class". 
The course used four different freeware: Padlet, Solibri Model Viewer, Tekla BIMsight and Tekla Field 3D. The students were asked to rate each piece of software in terms of usefulness to help them understand construction concepts and building structure, with 1 being 'not useful' and 5 being 'very useful' and also rate the same software in terms of difficulty to learn, with 1 being 'very easy' and 5 being 'very difficult'. Based on the survey data, Solibri Model Viewer and Tekla BIMsight were identified as the most useful software on the course; the least popular was Padlet, a web-based app which was used to understand the structure of the NZ construction industry, legislation, etc. (Table 5).

TABLE 5

\section{RATING OF THE COURSE CONSTRUCTION-SPECIFIC SOFTWARE IN TERMS OF USEFULNESS AND DIFFICULTY TO LEARN}

\begin{tabular}{|l||l|l||l|l|}
\hline Software & $\begin{array}{l}\text { Weighted number } \\
\text { of responses }\end{array}$ & $\begin{array}{l}\text { Rank order } \\
\text { usefulness }\end{array}$ & $\begin{array}{l}\text { Weighted number } \\
\text { of responses }\end{array}$ & $\begin{array}{l}\text { Rank order } \\
\text { difficulty }\end{array}$ \\
\hline $\begin{array}{l}\text { Solibri Model } \\
\text { Viewer }\end{array}$ & 95 & 1 & 65 & 2 \\
\hline Tekla BIMsight & 95 & $1^{\text {st }}$ equal & 65 & $2^{\text {nd }}$ equal \\
\hline Tekla Field 3D & 87 & 2 & 66 & 3 \\
\hline Padlet & 60 & 3 & 43 & 1 \\
\hline
\end{tabular}

In terms of difficulty to learn the software, students thought that the hardest ones were Tekla Field 3D, Solibri Model Viewer and Tekla BIMsight. The easiest one to learn was Padlet but at the same time it was considered the least useful. Only 3/24 students had some prior experience with Solibri Model Viewer on other degree courses and one with Padlet at school. The majority of students were unfamiliar with the software on the course. Despite this none of them rated any of the software as being 'very difficult' to learn. Approximately two thirds of the students, $15 / 24$, or $62.5 \%$, learn the software mostly by intuition or trying things out within the software. The remaining $9 / 24$ students, or $37.5 \%$, learn mostly by using the online tutorials provided on the course. None of the students reported on using other material sourced through general Google searches. The overwhelming majority of students, $23 / 24$, or $95.83 \%$, used their own laptops for their learning and to complete their course assignments while only one student learned mostly on their home desktop computer. Learning on mobile phones was the second preferred option. The least popular types of hardware among all students were tablets and desktop computers at Uni.

The general opinion was that the construction freeware on the course was not more difficult than commonly used MS Office applications (Word, Excel, Power Point) or SketchUp that a number of students were familiar with: "no big difference in terms of difficulty", "different but very useful for the future", "it was simpler most of the time", "the software on the course is easier", "the software on the course was more specialised, although to me they were equally straight forward to use". A few students thought that because they were unfamiliar with the software having more time to practise would help: "with the software you need a lot of practice to have a good understanding on its operation", "because I've used MS Office applications for many years I'm more familiar with them. That's why I think they are easier than the construction freeware on this course", "moderate, the difficulty is that this is the first time to use. Some functions and tools are difficult to find but we can use Google or watch the tutorial video to find them", "not really hard to understand, only that they were new to me so needed a few times to get a handle on them", "very similar. However, that freeware required more time to get used to", "Solibri and Tekla are obviously more difficult than Word \& PowerPoint since you can figure those out by intuition but it is not 
impossible to get used to Tekla and Solibri in a short amount of time", "the 3D models are usually complex, so software on the course is more difficult", "difficult because never used them before".

Students expressed a strong preference for individual work with almost two thirds of the students in favour, 15/24, or $62,5 \%$. Five students preferred to work in groups of three; 3 students to work in pairs; and 1 student preferred to work in a group of 4 . As the course had one group assignment using Padlet, students were asked about the way they communicated with each other outside class. Various social media platforms were widely used to collaborate with each other: WeChat, Email, Messenger, Google Docs, Facebook. WeChat was by far the most common social media app used by $50 \%$ of the students.

In summary, none of the students rated any of the course software as being 'very difficult' to learn. Learning happened mostly by intuition on own laptops. Students expressed a strong preference for individual work and used a variety of social media apps to collaborate with each other on group assessments.

\section{General Comments}

Overall the course got very positive feedback from all the students without an exception; 7 students qualified it as "useful". This is the range of other comments, basically each student had something to say: "useful for further study", "I've enjoyed it, last semester I took Technology 3 and I wish I had taken this course before doing that one", "the overall course was useful and good, learned the different software and construction process", "a good introduction to the software", "very interesting and enjoyable", "good informative course", "very good course, I have learned so much", "this is a course where you can actually learn something", "easy to understand, the level of difficulty is reasonable", "I think it's good, very informative for first year students", "perfect".

The students were asked to make suggestions for future course improvements. A third of the class, or 8 students, did not want anything changed and simply commented: "nothing", "same" or "good enough". Other students made suggestions for even more work to be included in the course: "more case studies", "more detail on topics", "have class activities", "a bit more work on reading plans", "more challenging tasks". The lack of prior construction knowledge and the challenge of learning different constructionspecific software within a compressed timeframe did not impact negatively on the overall feedback. However, a few students suggested more lecturer help with the freeware: "handhold on software tools and usage", "activities in class using software", "there should be guidance on how to use them". In terms of an overall course rating on a scale of 1 'very poor' to 5 'excellent', $23 / 24$ students, or $95.83 \%$, rated the course as 'good' (10 students) and 'excellent' (13 students); one student rated it as 'fair'.

In summary, the course received very positive feedback and very high overall course ratings. While a third of the class did not want anything changed, some students were willing to do even more work as they felt engaged in an "interesting" and "useful" course.

\section{DISCUSSION}

The students on the course, except one, fell into the category of "digital natives" described in the literature (Carlson, 2005; Farrow, Liu, \& Tatum, 2011; Prensky, 2001a; Yan, 2006; Zhao, McCoy, Bulbul, Fiori, \& Nikkhoo, 2015). The pre and post survey data revealed that overall there were no differences between the two groups of students, the ones born after 1980 and the others - born after 1995 in terms of their experiences with digital technologies. However, the student born in 1971 had a very different experience - although the purpose of each lesson and explanations were "very clear", the class work and assignments were "neither easy, nor hard" and overall the course was "hard work". Despite these challenges, the student thought that the most important thing that they learned on the course was actually the BIM software and rated the course as "excellent". As this was just one student, this result cannot be considered statistically relevant, but it does imply that there is a difference how "digital natives" and older generations experience digital technology.

All students, without an exception, had 'unlimited access' to the Internet and over $90 \%$ to mobile phones and personal laptops which were the most commonly used devices, none reported 'no access' to either of them. However, tablets and desktop computers did not prove that popular as half of the students 
had no access to them. Portability of the device is paramount (Farrow et al., 2011). This finding, which emphasizes student preferences for mobile devices, should be taken into consideration by tertiary institutions inclined on investing in computer labs or other types of fixed computer hardware for group work in lecture rooms.

All students, without an exception, started their tertiary studies with a good foundation, knowing how to produce Word documents and Power Points, create graphics and manipulate digital images. However, due to their diverse backgrounds, this may vary. The pre-survey data revealed that social networking software were in high daily use by all students with distinct preferences toward certain applications such as YouTube, WeChat, Facebook and Messenger while the post survey data showed that a variety of social media apps (WeChat, Email, Messenger, Google Docs, Facebook) were also widely used to collaborate with each other on group assessments. Teaching should provide opportunities for socialising through student interaction and group work (Oblinger \& Oblinger, 2005) and staying permanently connected, even over-connected, in a kind of digital hyper-activity (Prensky, 2001a; Prensky; 2001b; UNESCO, 2011). The natural inclination of the digital natives for connectivity, their excellent overall digital literacy and exceptional social networking software abilities should be capitalised upon when designing group assessments. The majority of students in this study expressed a strong preference for group work in class but favoured individual assessments. Students enjoy working in groups (Howe \& Strauss, 2000). Outside the classroom, they stayed connected in a more informal way talking about and sharing their experiences of the assessments without formally working on them together. This practice and the digital natives' background perhaps necessitate a rethink and clarification of general plagiarism rules.

The majority of students had not used any specialist construction software at the commencement of the Construction Communication and Documentation course. Despite this challenge, none of them rated any of the course freeware as being 'very difficult' to learn. Learning happened mostly by intuition or trying things out within the software on own laptops. This finding is consistent with the literature reporting on low tolerance for traditional lecturing, step-by-step guides and detailed instructions (Prensky, 2001a). Based on the survey data, Solibri Model Viewer and Tekla BIMsight were identified as the most useful software on the course. The general opinion was that the course freeware was not more difficult than commonly used MS Office applications (Word, Excel, Power Point) and helped to understand 3D models and various construction concepts in general. The purpose of integrating relatively easy construction-specific freeware on the course was to build on general digital literacy skills while avoiding the typical software steep learning curve and the associated considerable investment of time. The benefits of using BIM as part of the tertiary curriculum reported in the literature are around getting familiar with the software which students learn easily and creating an enhanced learning environment that facilitates unique learning experiences, engagement and motivation (Behzadan et al., 2016; Ghosh et al., 2015; Leal et al., 2018; Sacks, \& Barak, 2010; Vasilevski \& Birt, 2020).

Over $90 \%$ of the students in the class thought that the purpose of each lesson and the explanations provided were clear and they had a clear understanding of expectations. While digital technologies are central to the ways in which students experience their studies, they should not be considered as a substitute for good teaching practices as students seem to still value "conventional" approaches (Sunindijo, 2016). The majority of students provided very positive feedback on the course content and found the course "useful", "very helpful" "very informative", "interesting" and "fun"; they particularly valued the use of specialist construction software to aid their learning. Classroom delivery and assessment should be geared toward teamwork, experiential activities, structure, and the use of technology. Students' expectation is that education will be entertaining (Farrow et al., 2011).

\section{CONCLUSIONS AND FUTURE DIRECTIONS}

The data collection for this research was done before the COVID-19 pandemic. Although the pandemic did not have any impact on the results themselves, it is likely to have an impact on what education will look like in the future and therefore needs to be taken into consideration in the conclusions. Especially interesting will be to see any potential changes to learning spaces if remote learning becomes a permanent part of 
tertiary education. The findings of this research already suggest that traditional computer labs and lecture theatres are not necessarily the most suitable to support students' learning. Students use mobile devices and their learning happens through intuition and experiment rather than via lectures in a lecture theatre or a classroom, or via step-by-step guidance in a computer lab.

Although this particular sample group preferred individual assessments over group ones, this did not mean that the students would not have been in contact with each other even when completing the individual assessments. This natural inclination and skills for connectivity using social media applications need to be taken into consideration when designing course delivery and assessment. This might also have implications for how we consider plagiarism on a course. If we consider assessments as learning events and not just a tool to test students' learning, it would be beneficial, in terms of students' learning, to allow students to stay connected even with individual assessments. The aspiration in the AEC industry is towards more and more collaboration, surely this needs to be the aspiration within the AEC education as well. The boundaries between what is considered plagiarism and what is considered preferable collaboration need to be carefully examined and communicated.

The construction-specific freeware, which was introduced on the course, helped the students to understand complex construction concepts as intended. The course also succeeded in building on students' general digital literacy skills to learn new discipline specific software. It can be concluded that disciplinespecific digital technologies can be introduced successfully even to first year students.

The differences between Generation X (faculty) and Generation Y and Z (students) pose a challenge. It is not easy for the faculty to put themselves in the shoes of the digital natives, as their everyday use of digital technology is different in terms of preferred devices and applications, the way they use them, and the level of connectivity at any one time. The generational differences are likely to always exist, so the only way for the faculty to provide effective learning is to keep themselves updated in the ways students use digital technology and adjust the delivery and assessment methods accordingly.

The sample size was relatively small although it covered the whole "population" on the one course investigated. Due to the size of the sample it can be argued that the results might be somewhat different with another sample even in a similar setting. However, the fact that there were no outlying results within this particular digital natives' population, implies good reliability. In addition, the sample demographics provide a good representation of a wide age spectrum of digital natives from 1985 to 2001, covering both Generation Y and Generation Z. The findings do not offer a comparison between Generation X, and Generation Y and Z, as only one student belonged to Generation X which is why the results regarding Generation X cannot be considered statistically relevant. The aim of this research was not to compare these generations with each other, but to investigate how first-year construction students experienced the use of digital technology on their course.

Future research could test if the results are applicable to a wider AEC education context with larger samples. Another direction could be to study how digital natives cope with full professional desktop applications, and if they find the use as intuitive as the use of online and freeware applications. Comparisons between Generation X and Generation Y and Z could also be explored in an AEC education context focusing on a wide range of issues, not just software.

\section{REFERENCES}

Araki, T., \& Hirano, S. (2015). Development of cooperative education and basic engineering education: Aided by 3D CAD and 3D RP modelling. International Journal of Computer Applications in Technology, 5l(1), 80-85. https://doi.org/10.1504/IJCAT.2015.068403

Azhar, S., Khalfan, M., \& Maqsood, T. (2012). Building Information Modeling (BIM): Now and beyond. Australasian Journal of Construction Economics and Building, 12(4), 15-28. Retrieved from https://search.informit.com.au/documentSummary; $\mathrm{dn}=013120167780649 ;$ res=IELBUS

Azhar, S., Kim, J., \& Salman, A. (2018, November). Implementing Virtual Reality and Mixed Reality technologies in construction education: Students' perceptions and lessons learned. Paper 
presented at the $11^{\text {th }}$ Annual International Conference of Education, Research and Innovation, Seville, Spain. Retrieved from https://library.iated.org/publications/ICERI2018

Bademosi, F., Blinn, N., \& Issa, R.R.A. (2019). Use of Augmented Reality technology to enhance comprehension of construction assemblies. Journal of Information Technology in Construction, 24. Retrieved from https://www.itcon.org/

Behzadan, A.H., Vassign, S., \& Mostafavi, A. (2016). Teaching the millennium generation with Augmented Reality: Cases of the US education system. PARC Research in Architecture and Construction, 7(4), 265-272. https://doi.org/10.20396/parc.v7i4.8649284

Bennett, S., Maton, K., \& Kervin, L. (2008). The 'digital natives' debate: A critical review of the evidence. British Journal of Educational Technology, 39(5), 775-786. https://doi.org/10.1111/j.1467-8535.2007.00793.x

Brown, J.S. (2000). Growing up digital: How the web changes work, education and the ways people learn. Change: The Magazine of Higher Learning, 32(2), 11-20. https://doi.org/10.1080/00091380009601719

Carlson, S. (2005). The net generation goes to college. The Chronicle of Higher Education, 52(7). Retrieved from http://www.chronicle.com/article/The-Net-Generation-Goes-to-/12307/

Cavana, R.Y., Delahaye, B.L., \& Sekaran, U. (2001). Applied business research: Qualitative and quantitative methods. Milton, Qld: John Wiley \& Sons Australia, Ltd.

Denscombe, M. (2014). Good research guide: For small-scale social research projects (5th ed.). Maidenhead, England: McGraw-Hill/Open University Press.

Farrow, C.B., Liu, J., \& Tatum, M.C. (2011). Curriculum delivery and assessment for net generation construction students. International Journal of Construction Education and Research, 7(2), 109125. https://doi.org/10.1080/15578771.2011.575440

Ghosh, A., Parrish, K., \& Chasey, A.D. (2015). Implementing a vertically integrated BIM curriculum in an undergraduate construction management program. International Journal of Construction Education and Research, 11(2), 121-139. https://doi.org/10.1080/15578771.2014.965396

Henderson, M., Selwyn, N., \& Aston, R. (2017). What works and why? Student perceptions of 'useful' digital technology in university teaching and learning. Studies in Higher Education, 42(8), $1567-$ 1579. https://doi.org/10.1080/03075079.2015.1007946

Howe, N., \& Strauss, W. (2007). Millennials go to college. Great Falls, VA: LifeCourse Associates.

Kieferle, J., \& Woessner, U. (2015). BIM Interactive - about combining BIM and Virtual Reality. Paper presented at the $33^{\text {th }}$ eCAADe International Conference on Education and Research in Computer Aided Architectural Design in Europe, Vienna. Retrieved from http://papers.cumincad.org/data/works/att/ecaade2015_329.content.pdf

Kim, J., \& Irizarry, J. (2020). Evaluating the use of Augmented Reality technology to improve construction management students' spatial skills. International Journal of Construction Education and Research. Retrieved from https://doi.org/10.1080/15578771.2020.1717680

Kubicki, S., Guerriero, A., Leclercq, P., Nys, K., \& Halin, G. (2012, September). 4D modelling and simulation for the teaching of structural principles and construction techniques. Paper presented at the $30^{\text {th }}$ eCAADe Conference, France. Retrieved from https://halshs.archivesouvertes.fr/halshs-00857786/

Leal, B.M.F., Salgado, M.S., \& Silvoso, M.M. (2018, January). Impact of fourth industrial revolution in architecture undergraduate course. Paper presented at the ZEMCH 2018 International Conference, Melbourne. Retrieved from https://www.researchgate.net/profile/Monica_Salgado5/publication/323003640_Impact_of_Fourt h_Industrial_Revolution_on_Architecture_Undergraduate_Course/links/5a7bb $7790 \mathrm{f} 7 \mathrm{e} \overline{\mathrm{b}} 5 \overline{5} \mathrm{f} 65 \mathrm{ab}$ a9f/Impact-of-Fourth-Industrial-Revolution-on-Architecture-Undergraduate-Course.pdf

Liu, J., Olsen, D.A., \& Hein, M.F. (2011). Enhancing construction education using an online multimedia collection. International Journal of Construction Education and Research, 7(2), 85-108. https://doi.org/10.1080/15578771.2011.553211 
Lu, Y. (2017). Industry 4.0: A survey on technologies, applications and open research issues. Journal of Industrial Information Integration, 6, 1-10. https://doi.org/10.1016/j.jii.2017.04.005

Lukas, J. (2018). Immersive VR in the construction classroom to increase student understanding of sequence, assembly, and space of wood frame construction. Journal of Information Technology in Construction. Retrieved from https://www.itcon.org/

Ministry of Education. (2020). Tertiary Education Strategy. Retrieved from https://www.education.govt.nz/further-education/policies-and-strategies/tertiary-educationstrategy/

Nirmalakhandan, N., Ricketts, C., McShannon, J., \& Barrett, S. (2007). Teaching tools to promote active learning: Case study. Journal of Professional Issues in Engineering Education and Practice. 133(1), 31-37. https://doi.org/10.1061/(ASCE)1052-3928(2007)133:1(31)

Oblinger, D.G., \& Oblinger, J.L. (2005). Educating the net generation. Available from https://www.educause.edu/ir/library/PDF/pub7101.PDF

Oesterreich, T.D., \& Teuteberg, F. (2016). Understanding the implications of digitisation and automation in the context of Industry 4.0: A triangulation approach and elements of a research agenda for the construction industry. Computers in Industry, 83, 121-139.

https://doi.org/10.1016/j.compind.2016.09.006

Prenksy, M. (2001a). Digital natives, digital immigrants. On the Horizon, 9(5). Retrieved from https://marcprensky.com/writing/Prensky\%20\%20Digital\%20Natives,\%20Digital\%20Immigrants\%20-\%20Part1.pdf

Prenksy, M. (2001b). Digital natives, digital immigrants, Part II: Do they really think differently? On the Horizon, 9(6). Retrieved from http://www.marcprensky.com/writing/Prensky\%20\%20Digital\%20Natives,\%20Digital\%20Immigrants\%20-\%20Part2.pdf

Prensky, M. (2007). How to teach with technology: Keeping both teachers and students comfortable in an era of exponential change. Emerging Technologies for Learning, 2. Retrieved from http://partners.becta.org.uk/page_documents/research/emerging_technologies07_chapter4.pdf

Sacks, R., \& Barak, R. (2010). Teaching Building Information Modelling as an integral part of freshman year civil engineering education. Journal of Professional Issues in Engineering Education and Practice, 136(1). https://doi.org/10.1061/(ASCE)EI.1943-5541.0000003

Stange, F.P., \& Scheer, S. (2012). Virtual reality and scientific visualization applied in technical training in Brazilian construction. In Y. Lin \& S. Kang (Ed.). Proceedings of the 12th International Conference on Construction Applications of Virtual Reality (pp. 476-485). Taipei, Taiwan: National Taiwan University Press.

Sunindijo, R.Y. (2016). Teaching first-year construction management students: Lessons learned from student satisfaction surveys. International Journal of Construction Education and Research, 12(4), 243-254. https://doi.org/10.1080/15578771.2015.1121937

UNESCO Institute for Information Technologies in Education. (2011). Digital natives: How do they learn? How to teach them? Retrieved from https://iite.unesco.org/publications/3214698/

Vasilevski, N., \& Birt, J. (2020). Analysing construction student experiences of Mobile Mixed Reality enhanced learning in Virtual and Augmented Reality environments. Research in Learning Technology, 28. Retrieved from: https://journal.alt.ac.uk/index.php/rlt/article/view/2329/2603

Yan, S. (2006). Understanding generation Y. The Oberlin Review. Retrieved from http://www.oberlin.edu/stupub/ocreview/2006/12/08/features/Understanding_Generatio

Zezulka, F., Marcon, P., Vesely, I. \& Sajdl, O. (2016). Industry 4.0 - An Introduction in the phenomenon. IFAC-PapersOnLine, 49(25), 8-12. https://doi.org/10.1016/j.ifacol.2016.12.002n_Y.html

Zhao, D., McCoy, A.P., Bulbul, T., Fiori, C., \& Nikkhoo, P. (2015). Building collaborative construction skills through BIM-integrated learning environment. International Journal of Construction Education and Research, 11(2), 97-120. https://doi.org/10.1080/15578771.2014.986251 